\title{
Community Satisfaction Index for Public Services at attallassang Public Health Center Takalar Regency
}

\author{
Ruliaty \\ LuctureMuhammadiyah University, Makassar
}

\begin{abstract}
Public Health Center (PHC) of Pattallassang as health care unit is required to provide excellent service to the community. This study aims to determine the Community Satisfaction Index (CSI), quality of service and performance of services unit of Pattallassang PHC, TakalarRergency.This research uses descriptive quantitative approach with survey method. The sampling technique used was Accidental Samplingbythe number of respondents as many as 150 people ("number of elements" $+1 \times 10$ ) of the total population of the service recipient. Data analysis was done using Community Satisfaction Index values which are calculated by the weighted average value of each element of the service as many as 14 elements (Decree No.25/M.PAN/2/2004). The research results showed that the discipline value of service personnel (2.43), justice for obtaining services (2.35), and the certainty of the service schedule (2.41) got C point (less good), and one element with A point (very good) namely the certainty element of service charges (3.26). The performance of services unit of PHC Pattallassang, TakalarRegency is Good which had conversion interval values of CSI from 62.51 to 81.25, namely 69.54.
\end{abstract}

Keywords: service, satisfaction, quality, performance

\section{A. Background}

\section{Introduction}

Public services in Indonesia is still very low. Similarly, one of the conclusions of the World Bank reported in the World Development Report 2004 and the results of research of Governance and Desentralization Survey (GDS) 2002.There are two important issues which are prevalent in the field regarding public services. Dwiyanto (in Fanani, 2003) says that first, the magnitude of discrimination in services. Second, there is no certainty of cost and service time.

The empowerment policy of state apparatus in order to improve the quality of service should be done consistentlyby giving attention to the needs and expectations of society. Therefore, the government has issued a policy of empowerment for state apparatus in public services according to Decree of the Minister of State for Administrative Reform No. 81/1995, which states that the excellent service is a service that provides customer satisfaction, as well as Decree of Minister for Administrative Reform No. Kep/25/M.Pan/2/2004 regarding General Guidelines for Preparation of Public Satisfaction Index of Government Services Unit, and reinforced by the publication of a circular letter of the Minister of Administrative Reform and Bureaucratic Reform of the Republic of Indonesia No. 4/M/PAN-RB/03/2012 concerning the implementation of Community Satisfaction Index (CSI) survey in all public service provider units. The policy was created in response to public complaints and community demands on the quality of public services in all service units owned by the government.

Public Health Center (PHC) was developed since 1968 by the Ministry of Health of the Republic of Indonesia so that the people in the corners of Indonesia have access to basic health services. As a Technical Implementation Unit of Department of Health in districts/cities, PHC is responsible to organize to basic health effort of individuals and communities. (Ministry of Health, 1990). But unfortunately, for individual services, after more than four decades, PHC has not be chosen by the public to obtain health services. According to the RANDInstitute survey, people tend to come into private practice or traditional medicine than a health center Puskesmas (Frankerberget al., 1999).

PHC Pattallassang as one of the Health Department Technical Executive Unit KabupatenTakalar that provide services directly to the public, especially health services increasingly required to provide good services as a consequence that must be addressed by this agency in line with the duties and functions as public service agencies. In 2012 there were about 36665 visitors Pattallassang health centers, all of which would require a satisfactory service

B. Formulation of Problem: How Performance Health Center Services Unit Pattallassang Kabupaten Takalar?

C. Research Objectives: To know and analyze the performance of PHC Services Unit Pattalasang Kabupaten Takalar 


\section{A. Public Services}

\section{Literature Review}

\section{Definition of Public Service}

Kotler (in Sinambela, et al, 2006: 5) states that "Service is any activity that is beneficial in a collection or entity, and offers satisfaction, although the results are not tied to a physical product". Sampara (2000: 8) argues that the ministry is an activity or sequence of events that occur in the direct interaction between a person with another person or machine physically and provide customer satisfaction. Moenir (2000: 12) argues that the service is arising due to causes that are fundamental ideal and material.

Mahmuddin (2000: 76) developing a sense of service in the context of the services the organization defines the service: "All forms of activities undertaken by the human resources of an organization that is in accordance with the procedures and working mechanisms that have been outlined and regulated by the provisions of which are held by an organization in providing services the best to all individuals, groups or communities served. "

\section{Characteristics of the Services}

According to Parasuraman, et. al (1985), there are three main characteristics of services, namely: (a) Intangibility, means that the service is essentially the performance and results of the experience rather than an object. (B) heterogeneity, meaning that the service users or customers have needs that are very heterogeneous, and (c) Inseparability, means that the production and consumption of a service are inseparable.

\section{Principles of Public Service}

The principle of public services, consisting of: (a) transparency, (b) Accountability, (c) Conditional, (d) Participatory, (e) Equal rights, (f) the balance of rights and obligations.

\section{Service Standards}

The standard of service is a standardized measure in administering public services that must be obeyed by the giver or recipient of the service, at least the following:

a. Procedures, standardized for the giver and recipient of the service, including complaints.

b. Completion time, which is determined from the time of submission of application to completion of service, including complaints.

c. Cost of service, including the details set out in the process of service delivery.

d. Product services, outcomes of services that would be accepted in accordance with the conditions set.

e. Facilities and infrastructure, adequate by public service providers.

f. Competence attendant care providers, should be set appropriately based on the knowledge, expertise, skills, attitudes and behaviors needed.

\section{Quality of Public Services}

Goetsch and Davis (in Tjiptono, 2002: 4) defines "quality is a dynamic condition related to products, services, people, processes and environments that meet or exceed expectations". According to Kotler (1997: 49) quality is "all the attributes and characteristics of a product or service that affects the ability to satisfy stated or implied". Quality is a level of perfection is expected and control of such perfection to meet customer desires. Wyckof (in Tjiptono, 2002: 59)

In a further development Parasuraman, et. al. (1990), quality of service (services) are grouped into five dimensions:

a. Direct evidence (Tangible), which is a facility that can be viewed and used by companies in order to meet customer satisfaction.

b. Constraints (Reliability), the ability to provide service to customers as expected.

c. Responsiveness (Responsiveness), namely as responsiveness, willing to listen and respond to customers in an effort to satisfy customers.

d. Assurance (Assurance), the ability of employees in creating trust and confidence of customers.

e. Caring / Empathy (Empathy), namely the ability or willingness of employees provide personalized attention.

Meanwhile Lovelock (in Sedarmayanti, 2000: 203) also stated the need to watch out five principles for setting quality of service, namely:

a. Tangibles (touchable), such as the appearance of physical facilities, equipment, personnel and communication materials,

b. Reliability (reliable), the ability to form the promised service accurately and dependency.

c. Responsiveness (accountability), the sense of responsibility for the quality of service.

d. Assurance (guarantee), namely knowledge, behavior, and the ability of employees. 
e. Empathy (empathy), that individual attention to customers.

Based on a synthesis of the various research that has been done, Gronross (in Tjiptono, 2002) suggested six criteria of quality of service that is prepared well, which is as follows:

a. Professionalism and Skill. Customers found that service providers, employees, operational systems, and physical resources, have the knowledge and skills required to solve their problems in a professional manner (outcome-related criteria)

b. Attitudes and Behavior. Customers feel that the employee services (customer contact personnel) pay great attention to them and try to help solve their problems spontaneously and friendly (process-related criteria).

c. Accessibility and Flexibility. Customers feel that the service provider, location, hours of operation, employee and operational systems, designed and operated in such a manner so that customers can access these services easily. In addition, it is also designed with the intention to adjust demand and customer wishes in a flexible manner (process-related criteria)

d. Reliability and trustworthiness. Customers feel that no matter what happens or has been agreed upon, they can rely on service providers and their employees and the system in fulfilling the promise and do everything with the interests of the customer (process-related criteria)

e. Recovery. Customers realize that if anything goes wrong or something unexpected and unpredictable, then the service provider will immediately take action to control the situation and find appropriate solutions (process-related criteria)

f. Reputation and Credibility. Customers believe that the operation of the service providers are trustworthy and provide value / worth the additional costs incurred (image-related criteria).

\section{Research Methods}

\section{A. ResearchDesign}

The study design used in this research is descriptive quantitative research where this study was conducted to determine the value of an independent variable, either one or more variables, without making comparisons or linking to other variables.

\section{B. Population and Sample \\ 1. Population}

Population is the whole object or subject that is located in a region and meet certain requirements related to the research problem, or the whole unit or individual within the scope of which will be examined (Martono, 2010). The population in this study is the visitor / user PHC PattallassangTakalar, where the average visitor in PuskesmasPattallassang during October, November, December 2012, approximately 2,851 people per month.

\section{Sample}

Samples are part of the population that has the characteristics or specific circumstances to be studied. (Sugiono, 2010). Samples were taken by accidental sampling, ie patients who come for treatment to the health center when interviewed by investigators. Samples were taken as respondents as many as 150 people of the total population of the service recipient, the basis ( "Number of elements" +1 ) x $10=$ number of respondents $(14+1$ ) $\mathrm{x} 10=150$ respondents, in which the determination is based on the Decree of the Minister of Administrative Reform No. KEP / 25 / M.PAN / 2/2004 on General Guidelines for Preparation of Public Satisfaction Index (HPI) Service Unit Government Agencies.

\section{Data Collection Techniques}

Data collection techniques in this study using ways:

1. Questionnaires: Questionnaire method is used as the primary method in this study. Questionnaires are often referred to a questionnaire which is a list of questions presented / submitted to the respondent to answer.

2. Observation: Observations, carried out to obtain information and facts primer / region directly on the physical condition that is the result of field observations visually.

\section{Data Analysis Techniques}

Data analysis techniques in the study was conducted by using the value of Community Satisfaction Index (HPI) is calculated using the weighted average value of each service element. In calculating the IKM there are 14 elements or indicators that were examined. Each service element has the same weights with the following formula: 


\begin{tabular}{|c|}
\hline JumlahBobot 1 \\
Bobotnilai rata-rata tertimbang $=$ \\
JumlahUnsur
\end{tabular}

To obtain the value of SMEs used the following formula:

$$
\begin{aligned}
& \text { Total dariNilaiPersepsiPerUnsur } \\
& \mathrm{IKM}= \\
& \text { Total Unsur yang terisi }
\end{aligned}
$$

To facilitate interpretation of the SME ratings between 25-100, the results of the assessment above is converted to the value of the base 25 , with the following formula:

\section{IKM Unit pelayanan x 25}

Then from the calculation results that have been obtained, categorized as follows:

Value Perception, IKM Interval, Interval Conversions IKM,

Service Quality and Performance Unit

\begin{tabular}{|l|l|l|l|l|}
\hline Nilai ersepsi & Nilai Interval Ikm & Nilai Interval Konversi Ikm & Mutu Pelayanan & Kinerja Unit Pelayanan \\
\hline 1 & \multicolumn{2}{|l|}{} & & \\
\hline 2 & $1,00-1,75$ & $25-43,75$ & D & Tidakbaik \\
\hline 3 & $1,76-2,50$ & $43,76-62,50$ & C & KurangBaik \\
\hline 4 & $2,51-3,25$ & $62,51-81,25$ & B & Baik \\
\hline
\end{tabular}

Source: Kep.MenpanNomor: KEP/25/M.PAN/2/2004

\section{E. Validity Test Data}

Public opinion data that has been included in each questionnaire, compiled by compiled data collected respondents by age group, gender, education and employment last.

This information can be used to determine the profile of respondents, and the tendency of the answers given, for analysis by objectivity.

\section{A. Research}

\section{Identity of Respondents}

Identity of the respondents in this study include: the respondent's age, gender, education and employment of respondents last.Age of respondents in the study were classified into 4 groups of age, ie the age group 15-30 years, the age group 31-40 years, the age group $41-50$ years and age group 51 years and above. The results showed that the age of the respondents the most are aged 31-40 years is 60 respondents, and only 14 people aged 51 years and over. The rest of respondents aged 41-50 years as many as 40 people, and aged 15-30 years as many as 36.0 f the 150 respondents, 62 respondents are male and 88 are female, from the writer's observation that most visitors PuskesmasPattallassang are mothers with infants or small children for treatment.

\section{Assessment Results of Measurement Public Satisfaction Index}

Community Satisfaction Index (HPI) at the health center KabupatenTakalarPattallassang is based on 14 elements as contained in the decree Menpan No. KEP / 25 / M.PAN / 2/2004. To know in detail the research results can be seen in the following explanation.

\section{A. Procedures}

The element of the service procedure is the ease stages of PHC services delivered Pattallassang Kabupaten Takalar to the public in terms of the flow of services. 
Figure 1: Flow Pattallassang Health Center Outpatient Services KabupatenTakalar

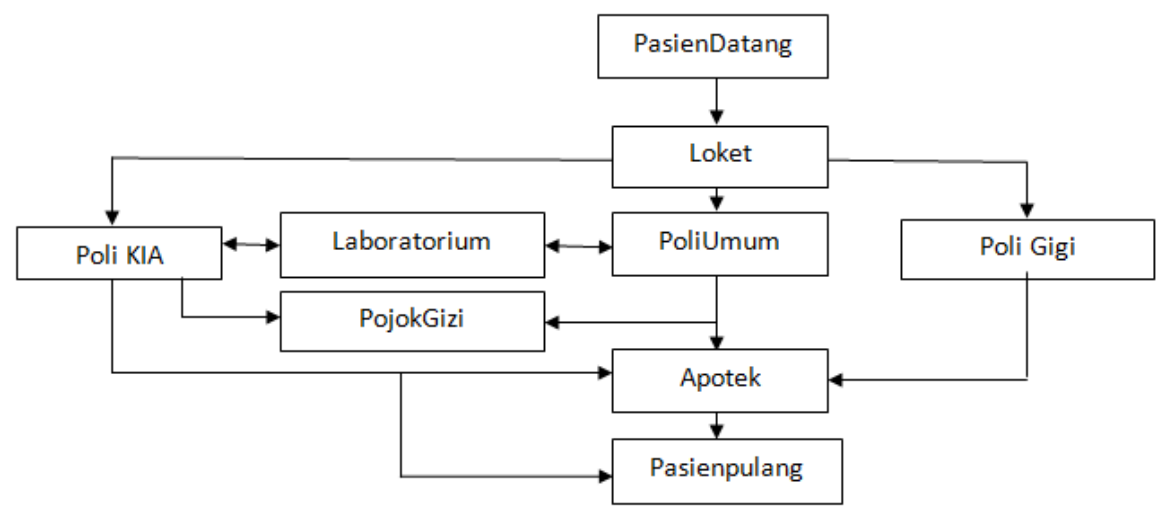

Source: Standard Health Center Services PattallassangKabupatenTakalar Number: 42 / PKM / PP / TU / III / 2011

Regarding the service procedure in PuskesmasPattallassangTakalar in 2013, the results showed that out of 150 respondents, none of which assess the service procedure in PuskesmasPattallasang not easy, three people expressed less easy, 119 people said easy, and 28 people expressed very easily. This means that the service procedure in PuskesmasPattallassangTakalar easy and uncomplicated.

\section{b. Terms of Service}

Elements of service requirements are technical and administrative requirements necessary to obtain the services in accordance with the type of service.Concerning the conditions of service in the health center PattallassangTakalar, the results showed that of the 150 respondents, 135 people judge according to the type of service they get, and as many as 15 people assess the requirements of existing services is less in accordance with the type of service.

\section{c. Clarity Services Officer}

Clarity of service personnel and the certainty that the existence of officers who provide services (name, position and authority and responsibility). Clarity regarding care workers at the health center Pattallassang Takalar, the results showed that out of 150 respondents, as many as 7 people rate is not clear, 82 people evaluate less obvious, 63 people considered clear, and 12 people judge very clearly.

From the results of the author's observation at health centers Pattallassang obtained the fact that most health workers in health centers PattallassangKabupatenTakalar not wear the nameplate, in addition to the uniforms of employees vary, there are wearing colorful clothes, some wearing white, especially on Friday and Saturday at the health center where employees wear batik Pattallassang diverse that it is unclear where the clerk, where visitors, even when the author wants to meet the head of the health center and head of the administration, concerned not been in his office for the head of the health center also doubles as pharmacist and head of administration doubles as a nurse.

\section{d. Discipline Service Officers.}

The discipline of service personnel include officers seriousness in providing services mainly to the consistency of working time according to applicable regulations.Concerning discipline Pattallassang care workers at the health center Takalar, the results showed that of the 150 respondents, 12 people assess the lack of discipline, lack of discipline 65 people rate, 70 people rate discipline, and 3 people judge very disciplined.

Respondents who rate the service personnel not discipline is the respondents who came at $07.30 \mathrm{pm}$ until $08.30 \mathrm{pm}$. This is because some of the doctors and nurses on duty came after $09.00 \mathrm{pm}$ so that patients feel tired of waiting.

\section{e. Responsibilities Service Officers.}

Service officer responsibilities include clarity of authority and responsibility of the officer in the administration and settlement services in Puskesmas PattallassangTakalar.

Regarding the responsibility of service personnel in health centers PattallassangTakalar, the results showed that of the 150 respondents, 20 people considered less responsible, 119 people considered responsible, and 11 rate it highly irresponsible.Every care workers should have the responsibility. Responsibility is the obligation to bear everything. Officers responsible service will perform its obligations. He was obliged to give answers and bore all of his action. If negligent in responsibility, there is a risk that must be borne. 


\section{f. Capability Service Officers}

Regarding the level of expertise and skills possessed care workers at the health center Pattallassang Kabupaten Takalar in providing / finishing services to the public, the results showed that of the 150 respondents, 31 people assess the underprivileged, 108 people considered capable, and 11 rate it highly capable.

In general it can be said that the care workers in health centers already have the competence Pattallassang as health care workers. Handling public / patients in health centers Pattallassang handled by officers according to its area, counters are handled by administrative personnel, Poli KIA handled by midwives, Poli General handled by nurses, Poli gear is handled by dental nurses, pharmacies served by pharmacists, and each poly in implementing duties in collaboration with general practitioners and dentists.

\section{g. Free Services}

Speed of service is the target of a similar service can be completed within the time specified by the health center PattallassangKabupatenTakalar as providers of care.Regarding the speed of service, the results showed that out of 150 respondents, as many as 15 people rate is not fast, 42 people rate fast enough, 88 people assess quickly, and 5 people judge very quickly.

From the author's observation that for one patient at the health center takes time in counter 5 minutes, in the examination room 10 to 15 minutes and at the recipe 10 minutes, so for one patient visit takes 25 to 30 minutes at a time crowded ie from 09:00 pm - 11:00 pm. According Gronross good service quality should have the attitudes and behavior that the customer feels that the service employees pay great attention to them and try to help solve their problems spontaneously and friendly.

\section{h. Courtesy and hospitality Officer}

The attitude and behavior of staff in providing services to the community as polite and friendly as well as respect and respect are the expectations of visitors. Regarding the courtesy and friendliness of service personnel in health centers PattallassangTakalar, the results showed that of the 150 respondents, 40 people who express service personnel are less courteous and friendly, 104 respondents expressed polite and friendly, and 6 stated very polite and friendly.

Officers were courteous and friendly service will certainly leave a deep impression in the hearts of the people / patients, health centers Pattallassang motto is Smiles, greetings and Sapa (3S), this motto should be realized by all officers Pattallasang services at the health center.All the public / customers according to Rust, et.al expect ideal expectation, namely the level of optimum performance or best expected to be acceptable to consumers. The hospitality includes patience, attention and friendship in the contact between the officer and customer services.

\section{i. Cost reasonableness Services}

The reasonableness of the service charge is the affordability of the public to the amount of the fees imposed by the service unit in PuskesmasPattallassangTakalar.The results showed that of the 150 respondents, 125 people considered reasonable service charge and 25 people rate is very reasonable.

Most of the services in PuskesmasPattallassang is free except for the Certificate of Health bodied fee of Rp. 10,000 and also for general patients for the first time been charged Rp. 2,000 to get the control card. People who use public health services Pattallassang never charge service fees beyond a predetermined in accordance with the standards of health center services Pattallassang, so no respondents who assess the cost of health center services Pattallassang less fair or not fair.

\section{j. Certainty Cost of Services}

Certainty is a match between the cost of service fees paid by the public as users of the service at a cost that has been set by PHC PattallassangKabupatenTakalar as health providers.The results showed that of the 150 respondents, 111 people considered that the costs incurred in accordance with a predetermined fee and as many as 39 people expressed very appropriate.

PHC Pattallassang as health care unit has been running a free health program, which means all health services except for the maintenance condition paper is free or not free of charge and there has never been any complaints of customers stating they charge should not be.

\section{k. Leisure Environment}

Environmental comfort is a condition of service facilities and infrastructure were clean, neat, and organized so as to provide comfort to the recipient of the service.Regarding environmental comfort PHC PattallassangKabupatenTakalar, the results showed that of the 150 respondents, 43 people considered less convenient, comfortable assess 104 people, and three people considered extremely comfortable. 
Although the health center waiting room Pattallassang narrow, but is perceived by the respondents as comfortable as they are not too hot, where the reception area is quite open, ample parking for the vehicle to accommodate the public / customers. But on the other hand, some visitors complained WC for patients / visitors that the water is dirty, even the toilet door can not be locked. Besides chairs in the waiting room so small that most patients / visitors had to stand because they do not get a seat.

\section{1. security Services}

Security service is a guarantee of the level of environmental safety or health center Pattallassang Kabupaten Takalar means used, so that people feel at ease to obtain the services of the risks resulting from the implementation of service.

The results showed that of the 150 respondents, as many as 7 people assess the security services at the health center Takalar Pattallassang less secure, 114 people considered safe, and 29 rate it highly secure. This indicates that the health center PattallassangKabupatenTakalar been conducting health services based on the SOPs of each Poli and has been equipped with appropriate facilities and infrastructure so that people feel safe to seek treatment at the health center.

\section{Discussion}

Respondents who studied at the health center KabupatenTakalarPattallassang as many as 150 people at most are from the age group below 31- 40 years, with the majority of the female gender.In the 14 elements of the service that is the benchmark for assessing the level of satisfaction of the community health center services PattallassangKabupatenTakalar, disciplinary element of service personnel, to justice to get service, and an element of certainty of service schedules get value $\mathrm{C}$ which is less good. This shows a lack of quality of these three elements, because the quality of service associated with the fulfillment of the expectations or needs. Means the three elements are not met the expectations of the community / health center patients Pattallassang.

Elements disciplinary care workers rated poorly by the public / patient. Discipline is the seriousness of service personnel officers in providing services mainly to the consistency of working time according to applicable regulations. In a public service must be supported by the quality of human resources through the discipline of service personnel which is an embodiment of attitudes in the workplace.

According Moenir, discipline-care workers in providing services to the community is a discipline in the implementation of tasks and job consists of two forms of discipline, that discipline and disciplinary action time, both forms of discipline that integrates the realization of the work.

Timeliness of service, justice of the revenue service and discipline of service personnel who rated poorly by the public / patients, which means the principle of reliability (reliability) Pattallassang health center should be considered. Reliability is the ability to provide the promised service with immediate, accurate and satisfactory. This means Pattallassang health centers must provide appropriate services since the first moment (right the first time). It also means that health centers Pattallassang should be able to fulfill his promise to be a unit of excellent service.

Pattallassang promise of health center services are:

a. Provide the best service and wholeheartedly to all the people / patients who request our services to the health center.

b. Prioritizing services to underprivileged people, both inside and outside the building.

c. Resolving services in accordance with the timetable that has been set.

d. Friendly and smiling in providing services to the public.

e. Providing ease of obtaining health care.

f. Remind friends not to take action that is detrimental to society.

The lack of quality of service can occur when health care workers do not understand precisely what people / patients. Providers of services may think that patients want better public facilities, but patients may be more concerned with the responsiveness of nurses.

Responsiveness (responsiveness) is the willpower of the staff to help consumers and provide services to respond. Responsiveness can mean response or alertness Pattallassang care workers in health centers in helping people / patients and provide fast service. The results showed that the issues of public complaints / patients is how long they wait, due to the lack of discipline of service personnel and service schedules inaccuracy.

One of the principles of public service is of equal rights, non-discriminatory in the sense of ethnicity, race, religion, class, gender and economic status, this means PuskesmasPattallassang as public service units must treat the public / patients to justice without distinction of race, race, religion, class, gender and economic status. Service is arising because (Moenir 2000: 12):

1. The existence of a sense of love and affection, and are willing to serve and sacrifice. 
2. The existence of convictions for and the importance of helping each other human beings, which is the motion instinctalready inherent in man.

3. There is a belief that doing good to others is a must, so that the initiative emerged from the rescue aid giver.

Of the 14 elements studied, the 10 elements included in category B (good). Good quality services at PHC Pattallassang for their empathy (empathy) and assurance (guarantee). Empathy and assurance demonstrated by providing the convenience of service, courtesy and friendliness in the service, the speed of the serve, the ability to serve. Care workers must also understand the public / customers, meaning that customers sometimes like a child who wants everything or customers sometimes like parents who nag. By understanding the public / customer, it does not mean service officers feel "lost" and had "agreed" public opinion / patient, but at least try to compromise not to take the fight.

PuskesmasPattallassang as health centers free health continues to improve the quality of His ministry with the vision of "Creating PHC Pattallassang into a health center that provides health care service" and of the results of Community Satisfaction Index obtained the quality of health center services Pattallassang is B, then the performance of the unit of health center services Pattallassang is good value interval IKM conversion is 62,51- 81.25. This means that they are satisfied with the performance of health center services officer Pattallassang.

\section{Conclusion}

A. Conclusion: From the results it can be concluded penilitian some important issues about health care in health centers PattallassangTakalar, as follows:

1. Value of service personnel discipline (2.43), obtain justice services (2.35), and the certainty of the service schedule (2.41) got a C (not good), and one element with a value of A (very good) that is the element assurance service charges (3.26).

2. Performance of health center services unit PattallassangKabupatenTakalar is 'Good' which is at a value IKM conversion interval from 62.51 to 81.25 is 69.54 .

\section{B. Suggestions}

Based on the conclusions from these results, it can be given the following advice:

1. To improve the performance of service units, health centers PattallassangKabupatenTakalar as health care unit can do things as follows:

a. Greet patients with a smile and a warm greeting,

b. Explore and help find health problems of the patient,

c. Have a genuine intention to resolve the health problems of patients with the best capabilities

d. Treat all patients fairly regardless of social status, ethnicity, religion, or politics.

e. health services provided are appropriate service standards.

2. To the other researchers who are interested in researching the same field would be able to develop a more profound areas of study for the sake of science, especially in the field of public administration.

\section{References}

[1] Azwar, A, (1996). MenjagaMutuPelayananKesehatanAplikasiPrinsipLingkaranPemecahanMasalah. Jakarta:PustakaSinarHarapan.

[2] Barata, AtepAdya, (2003). Dasar-dasarPelayanan Prima, Jakarta: PT. Elex Media Komputindo.

[3] Danakusuma, (2002). PerkembanganKesehatanMasyarakatdanKedokteranKomunitas, Jakarta:Buletin FK-UI.

[4] DepartemenKesehatan RI, (1990). PedomanKerjaPuskesmasJilid I, SistemUpayaKesehatanPuskesmas, Jakarta.

[5] Fanani, Ahmad Zaenal, (2008). OptimalisasiPelayananPublik: Perspektif David Osborne dan Ted Gaebler, (Online) (http://www.badilag.netdiakses 12 Maret 2013).

[6] Frankerberg. et al, (1999), User's Guide for the Indonesia Family Life Survey, Wave². Santa Monica, RAND.

[7] Gronroos, Christian, (1990). Services Management and Marketing: Managing the Moments of Truth in Service Competition. Massachusetts, Lexington Books

[8] Jasfar, Farida, (2005). ManajemenJasaPendekatanTerpadu. Bogor: Ghalia Indonesia.

[9] Juliantara, Dadang, dkk, (2005). PeningkatanKapasitasPemerintahDaerahdalamPelayananPublik. Yogyakarta:Pembaruan.

[10] KeputusanMenteriPendayagunaanAparatur Negara Nomor. 63/KEP/7/2003 tentangPrinsip-prinsipPelayananPublik.

[11] KeputusanMenteriPendayagunaanAparatur Negara Nomor.25/M.PAN/2/2004

[12] tentangPedomanUmumPenyusunanIndeksKepuasanMasyarakat Unit PelayananInstansiPemerintah.

[13] Kotler, Philip, (1997). Marketing Management “Analysis, Planning, Implementation and Control” (9th ed.). New Jersey: Prentice Hall International, Inc

[14] Kurniawan, Agung, (2005). Transformasi Pelayanan Publik. Yogyakarta:Pembaruan

[15] LembagaAdministrasi Negara, (2003). PenyusunanStandarPelayananPublik, Jakarta: LAN

[16] LembagaAdministrasi Negara, (2006). StrategiPeningkatanKualitasPelayananPublik, Jakarta: LAN

[17] Lovelock, Christopher.Hdan Wright, Lauren. K, (2005). ManajemenPemasaranJasa. Jakarta:Indeks.

[18] Lupiyoadi, Rambat, (2001). ManajemenPemasaranJasa, Jakarta:SalembaEmpat,

[19] Mahmuddin, Adnan, (2000), KarakteristikPelayananBerkualitas, Jakarta: Raja GrafindoPersada. 
[20] Martin, L. L danKettner, P. M, (1996). Measuring Performance of Human Service Programs. Sage London-New Delhi, Publication International Educational and Profesional Publisher. Thousand Oaks.

[21] Martono, Nanang, (2010). MetodePenelitianSuatuPendekatan Proposal. Jakarta:BumiAksara

[22] Moenir, A.S, (2000), ManajemenPelayananUmum di Indonesia, Jakarta:BumiAksara.

[23] Nurcholis, Hanif, (2005), TeoridanPraktikPemerintahandanOtonomi Daerah, Jakarta: PT. Grasindo

[24] Parasuraman, et al, (1985). Quality Counts In Service too, New York. Business Horisontal Vol. 28 No.3

[25] Parasuraman, et al, (1990). "Delivering Quality Service Balancing Customer Perseptions and Expecttation" New York, The Free Press.

[26] Payne, Adrian, (1993). PemasaranJasa. Yogyakarta:Andi

[27] Pohan, S Imbalo, (2007). jaminanmutulayanankesehatan, Dasar-as arpengerti and anpenerap annya, Jakarta: PenerbitBukuKedokteran EGC

[28] Sampara, Lukman, (2000). ManajemenKualitasPelayanan, Jakarta: STIA LAN Press. 